\title{
Effects of habitat and land use on breeding season density of male Asian Houbara Chlamydotis macqueenii
}

\author{
M. A. Koshkin ${ }^{1}$ (D) R. J. Burnside ${ }^{1}$ N. J. Collar ${ }^{2}$ J. L. Guilherme ${ }^{1} \cdot$ \\ D. A. Showler ${ }^{1} \cdot$ P. M. Dolman ${ }^{1}$
}

Received: 4 August 2015/Revised: 15 October 2015/Accepted: 11 December 2015/Published online: 25 February 2016

(C) The Author(s) 2016. This article is published with open access at Springerlink.com

\begin{abstract}
Landscape-scale habitat and land use influences on Asian Houbara Chlamydotis macqueenii (IUCN Vulnerable) remain unstudied, while estimating numbers of this cryptic, low-density, over-hunted species is challenging. In spring 2013, male houbara were recorded at 231 point counts, conducted twice, across a gradient of sheep density and shrub assemblages within $14,300 \mathrm{~km}^{2}$ of the Kyzylkum Desert, Uzbekistan. Four sets of models related male abundance to: (1) vegetation structure (shrub height and substrate); (2) shrub assemblage; (3) shrub species composition (multidimensional scaling); (4) remote-sensed derived land cover (GLOBCOVER, 4 variables). Each set also incorporated measures of landscape rugosity and sheep density. For each set, multi-model inference was applied to generalised linear mixed models of visit-specific counts that included important detectability covariates and point ID as random effects. Vegetation structure received strongest support, followed by shrub species composition and shrub assemblage, with weakest support for the GLOBCOVER model set. Male houbara numbers were greater with lower mean shrub height, more gravel and flatter surfaces, but were unaffected by sheep density. Male
\end{abstract}

Communicated by T. Gottschalk.

Electronic supplementary material The online version of this article (doi:10.1007/s10336-015-1320-4) contains supplementary material, which is available to authorized users.

M. A. Koshkin

makoshkin@gmail.com

1 School of Environmental Sciences, University of East Anglia, Norwich NR4 7JT, UK

2 BirdLife International, Pembroke Street, Cambridge CB2 3QZ, UK density (mean $0.14 \mathrm{~km}^{-2}$ ) estimated by distance analysis differed substantially among shrub assemblages, being highest in vegetation dominated by Salsola rigida, high in areas of S. arbuscula and Astragalus, respectively, lower in Artemisia and lowest in Calligonum. The study area was estimated to hold 1824 males (CI 1645-2030). The spatial distribution of relative male houbara abundance, predicted from vegetation structure models, had the strongest correspondence with observed numbers in both model calibration and the subsequent year's data. We found no effect of pastoralism on male distribution, but potential effects on nesting females are unknown. Density differences among shrub communities suggest extrapolation to estimate country- or range-wide population size must take into account vegetation composition.

Keywords Extensive grazing - Pastoralism ·

Sustainability - Rangeland management - Detectability . Density estimation $\cdot$ Spatial distribution model $\cdot$ Bustard

\section{Zusammenfassung}

Effekte von Habitat und Landnutzung auf die Populationsdichte der Asiatischen Kragentrappe Chlamydotis macqueenii zur Brutzeit

Landschaftsweite Habitat- und Landnutzungseinflüsse auf die Asiatische Kragentrappe Chlamydotis macqueenii („Gefährdet“ laut Roter Liste der IUCN) wurden bisher nicht untersucht, während eine Abschätzung der Bestände dieser versteckt lebenden, überjagten Art mit geringer Abundanz eine Herausforderung darstellt. Im Frühjahr 2013 wurden männliche Kragentrappen in 231 doppelt ausgeführten Punktzählungen gezählt, über unterschiedliche Dichten von Beweidung durch Schafe und 
Strauchbewuchs hinweg, in einem $14.300 \mathrm{~km}^{2}$ großen Gebiet der Kyzylkum-Wüste in Usbekistan. Vier Modelle stellten den Zusammenhang der Abundanz der Männchen dar zu: (1) Vegetationsstruktur (Strauchhöhe und Substrat), (2) Strauchdichte, (3) Zusammensetzung der Straucharten (Multidimensionale Skalierung), (4) Landbedeckung, hergeleitet aus Fernerkundungsdaten (GLOBCOVER, 4 Variable). Jeder Datensatz enthielt auch Maße für die Rauheit der Landschaft sowie die Beweidungsdichte durch Schafe. Für jeden Datensatz wurde eine Multi-Modell Inferenz auf GLMMs von Zahlen einer bestimmten Zählung angewandt, die wichtige Kovariate zur „Entdeckbarkeit" und Punkt-ID als Random Effect einschloss. Vegetationsstruktur wurde am stärksten unterstützt, gefolgt von Zusammensetzung der Straucharten und Strauchdichte, mit der schwächsten Unterstützung für die Daten aus dem GLOBCOVER Modell. Die Anzahl männlicher Kragentrappen war größer mit geringerer mittlerer Strauchhöhe, mehr Schotter und flacheren Oberflächen, waren aber unbeeinflusst von der Beweidungsdichte durch Schafe. Die Abundanz von Männchen (durchschnittlich $0,14 \mathrm{~km}^{-2}$ ), geschätzt anhand einer Distanzanalyse, unterschied sich wesentlich zwischen verschiedenen Zusammensetzungen von Sträuchern: sie war am höchsten in Vegetationen, die von Salsola rigida dominiert wurde, hoch in Gegenden mit S. arbuscula und Astralagus, geringer für Artemisia und am niedrigsten mit Calligonum. Die Anzahl der Männchen im Untersuchungsgebiet wurde auf 1824 (1645-2030) geschätzt. Die räumliche Verteilung der relativen Abundanz der männlichen Kragentrappen, vorhergesagt aus Vegetationsstruktur-Modellen, hatte die stärkste Übereinstimmung mit den beobachteten Zahlen sowohl in der Modellkalibration als auch den Daten des Folgejahres. Wir fanden keinen Effekt von Hütehaltung auf die Verteilung der Männchen, aber ein möglicher Effekt auf nistende Weibchen ist unbekannt. Dichteunterschiede zwischen Strauch-Gesellschaften legen es nahe, dass zur Extrapolation einer landes- oder gebietsweiten Populationsgröße die Zusammensetzung der Vegetation berücksichtigt werden muss.

\section{Introduction}

Sparsely distributed cryptic animals present a serious challenge to researchers. Habitat suitability modelling allows the relative importance of environmental factors to be assessed and supports distribution and relative density mapping of such species (Peterson 2006; Hirzel and Lay 2008), and this can be used to prioritise areas for management and protection (Renwick et al. 2012; Johnston et al. 2015). However, estimating their actual population size is much more problematic, although this is a necessary requirement for evidence-based management of exploited populations (Waber et al. 2013).

The Asian Houbara Chlamydotis macqueenii is a large but cryptic terrestrial bird of sparsely vegetated semi-arid environments stretching from Sinai (Egypt) to Mongolia. Poorly regulated and unsustainable hunting and trapping on both migration routes and wintering grounds (Combreau et al. 2001) have been blamed for declines in Kazakhstan (Tourenq et al. 2004, 2005; Riou et al. 2011), which hosts an estimated $77 \%$ of the global population (Goriup 1997), resulting in Asian Houbara being listed by the International Union for Conservation of Nature (IUCN) as Vulnerable (BirdLife International 2015). Habitat degradation from agricultural intensification and overgrazing, combined with human disturbance, is thought also to be affecting the species in parts of its range (Goriup 1997; Combreau et al. 2001, 2002), albeit with little published evidence.

The conservation response to the plight of the Asian Houbara has focused on large-scale captive breeding and release (Seddon et al. 1995; Combreau and Smith 1998; Chargé et al. 2014) rather than on improved regulation to render hunting sustainable. However, a further possible measure to partly compensate for the effects of hunting and trapping is the management of local wild populations within the core breeding range. This could take the form of identifying and mitigating region-specific issues affecting habitat quality and extent, local abundance and demography. To establish an evidence base for such management it is necessary (1) to establish the degree to which houbara abundance varies with habitats and with the anthropogenic pressures exerted on them, and (2) to reach a robust estimate of local population size as a benchmark against which to monitor the effects of future interventions.

Several studies have related land use factors to density and distribution of resident African Houbara C. undulata across its range, and indicated that breeding birds are negatively affected by direct and indirect human disturbance, avoiding settlements, major roads, wells, shepherds' camps and agricultural fields (Carrascal et al. 2006, 2008; Hingrat et al. 2008; Chammem et al. 2012). In contrast, a study in Iran showed wintering Asian Houbara were associated with croplands (Aghainajafi-Zadeh et al. 2010), while breeding season distribution of male Asian Houbara was not found to be influenced by pastoralism in Uzbekistan (Koshkin et al. 2014).

Most studies assessing habitat use by wild houbara of both species have operated at the micro-scale: the immediate vicinity of male display sites $(10 \mathrm{~m} \times 10 \mathrm{~m}$, Yang et al. 2002b), nests $(10 \mathrm{~m} \times 10 \mathrm{~m}$, in both Yang et al. 2002b; Aghanajafizadeh et al. 2012), tracks (2.5-m width, Launay et al. 1997b) or telemetry locations $(50 \mathrm{~m} \times 3 \mathrm{~m}$, Combreau and Smith 1997; 100-m radius, Hingrat et al. 
2007). However, heterogeneity of topography, vegetation and soil, and a need for conservation planning on a regional extent, necessitate the study of how density varies at landscape scales rather than at micro-site scales. Other studies have examined the influence of habitat and land use characteristics on houbara presence/absence at larger spatial scales, i.e. for $500 \mathrm{~m}$ walked transects (Carrascal et al. 2008) or $20 \mathrm{~km} \times 20 \mathrm{~km}$ grid cells (Chammem et al. 2012). Van Heezik and Seddon (1999) examined Asian Houbara habitat selection among seven habitats (defined by landform and substrate) in Saudi Arabia, using a sample of sightings $(n=229)$ collected along standardised drives within a study area of about $750 \mathrm{~km}^{2}$, and found that probability of selection for different habitats varied with season. However, sex was not considered and analysis of habitat selection was performed on observation data merged across four years to obtain sufficient sample sizes.

Density estimates are necessary for the extrapolation of population sizes, which can then potentially be used to inform sustainable harvest quotas and the assessment of conservation status. However, few recent estimates exist for migrant houbara population sizes in the breeding range from Central Asia to Mongolia. In the mid-1990s the global population of the Asian Houbara was estimated at 39,000-52,000 individuals, of which $77 \%$ were in Kazakhstan and $15 \%$ in Uzbekistan (Goriup 1997). This estimate, however, extrapolated country-wide numbers from local estimates (Gubin 1992; Mitropolsky et al. 1996). Subsequent studies that provided density estimates for several subpopulations in Kazakhstan (Tourenq et al. 2004, 2005; Riou et al. 2011) experienced methodological limitations (see "Discussion"), while for Uzbekistan the two assessments available were considered preliminary and provisional (Launay et al. 1997a; Koshkin et al. 2014).

To our knowledge, no previous study has sought to establish regional population sizes by comparing houbara breeding densities among habitats at the landscape scale. Here, we assess the effects of habitat and human land use on houbara abundance and provide the first robust estimate of density and a regional population size for this species.

\section{Methods}

\section{Study area}

The study area $\quad\left(39.34-40.56^{\circ} \mathrm{N} \quad 62.21-65.20^{\circ} \mathrm{E}\right.$, $170-400 \mathrm{~m}$ above sea level; approximately $14,300 \mathrm{~km}^{2}$ ) is located in the Bukhara District of Uzbekistan, within the Kyzylkum part of the Southern Central Asian Desert (Fig. 1). The terrain is predominantly flat to gently rolling, bounded to the north and east by low dry mountains, and to the south-east by irrigated croplands and permanent settlements. Plant communities are dominated by droughtresistant and halophytic shrubs, with shrub assemblage and vegetation structure varying with landform and substrate (gypseous soils, consolidated or loose sands), resulting in a mosaic of habitats at the landscape scale. Although largely unpopulated with only a few scattered small settlements, parts of the area are grazed in spring by mixed flocks of sheep (predominantly) and goats (hereafter 'sheep'). Most such livestock are managed from seasonal camps and their distribution is limited by the distribution of functioning wells and to areas to which water can be transported. Thus, livestock densities are highest in areas closer to settlements and permanent water sources, leaving substantial areas of the desert sheep-free (Koshkin et al. 2014).

\section{Sampling of houbara}

Houbara are shy and difficult to see. However, during the breeding season (March-May) displaying males (and also floating males; see SOM, "Discussion" section) are conspicuous and can be apparent from long distances. This provides an opportunity for male population assessment with a relatively high degree of accuracy. From 24 March to 19 May 2013, two counts several weeks apart were made at each of 231 points across the study area. Counts were repeated at each location to reduce sampling error from weather or time of day. Subsequent analyses of visitspecific counts allowed these factors, as well as season (detectability was expected to decrease with season progress), to be controlled for in analyses of abundance, while separate analysis of the maximum count across two visits did not account for these covariates. Point count locations were randomly selected (excluding known unsuitable breeding habitats, e.g. wetlands, mountains, irrigated and built-up areas), originally stratifying sampling effort across four shrub assemblages as mapped by Rachovskaya (1995): Artemisia, Salsola spp., Astragalus and Calligonum, following Koshkin et al. (2014). Locations were a minimum of $4 \mathrm{~km}$ apart to avoid pseudo-replication and reduce spatial autocorrelation. The classification and distribution of shrub assemblages were subsequently refined using vegetation data collected during this study, providing the following revised distribution of sampling locations: Artemisia $\left(2873 \mathrm{~km}^{2}\right), \quad n=33 ; \quad$ Salsola arbuscula $\left(3904 \mathrm{~km}^{2}\right), n=67 ;$ S. rigida $\left(2180 \mathrm{~km}^{2}\right), n=36 ;$ Astragalus $\left(3778 \mathrm{~km}^{2}\right), n=69$; and Calligonum $\left(1603 \mathrm{~km}^{2}\right)$, $n=26$ (Fig. 1). For a full description of vegetation sampling, classification and assemblages see (SOM, "Introduction" section).

Each count was conducted from the most appropriate vantage point (highest point, typically a small rise) within $400 \mathrm{~m}$ of the location originally selected in GIS, with the second count conducted from the same point. Each point 


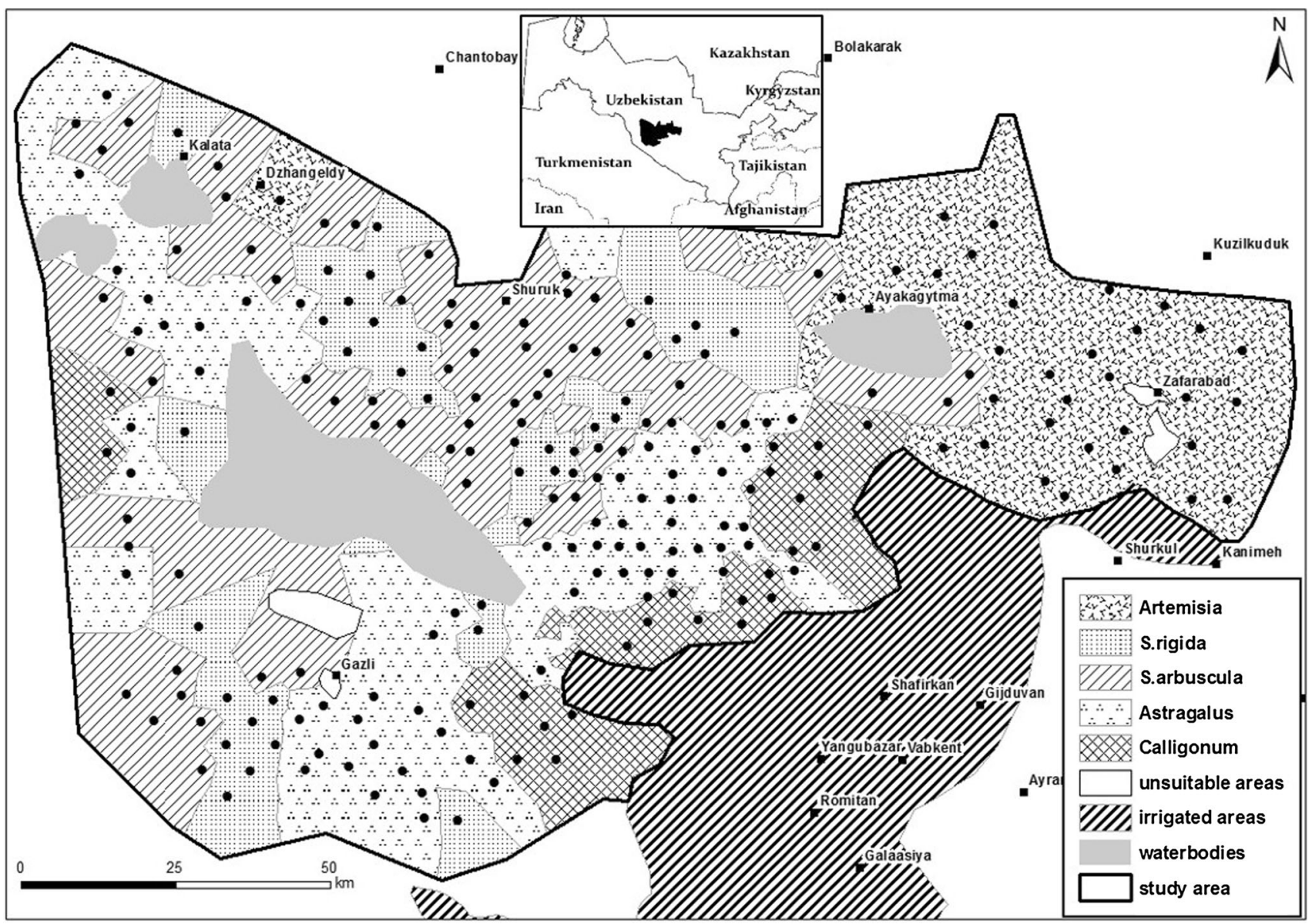

Fig. 1 Study area within Bukhara District of Uzbekistan, Southern Kyzylkum Desert, showing point count locations (black dots) in relation to five shrub assemblages classified during this study

count (an initial scan with binoculars followed by extensive scanning with a $20-60 \times$ telescope) lasted 30 min and was undertaken by a single observer during the period of peak male display activity, i.e. within $3 \mathrm{~h}$ after sunrise and $2 \mathrm{~h}$ before sunset (Combreau and Launay 1996). For each houbara or houbara group observed, the sex, age, number of individuals, distance from observer (measured by laser rangefinder up to $1400 \mathrm{~m}$ ) and activity (flying, walking, standing, crouching and/or displaying) and time of observation were recorded. Combination of plumage and structure of head and neck, as well as relative size of individuals in a group, was used to sex non-displaying birds. Observations beyond $1400 \mathrm{~m}$ could not be reliably measured by rangefinder and were, therefore, excluded from further analysis to avoid error and potential bias in density estimation (Buckland et al. 2001). As weather conditions may affect behaviour and, thus, detectability, wind strength was recorded during each point count $(0=$ no wind, $3=$ strong wind; see Table 1). Other conditions, such as fog and morning dew, which could affect a bird's behaviour and visibility, were not encountered during the study, whereas counts were not conducted during rain.

\section{Detectability covariates and estimates of male houbara density and numbers}

Six a priori factors, date, visit, time, wind, shrub height and landscape rugosity (a measure of terrain unevenness; $D E M$ $S D$ ), were postulated to affect houbara detectability (see Table 1). The first four may influence the incidence of male display, while shrub height and landscape rugosity could influence visibility (SOM, "Methods" section). Their effects on detectability were examined in a series of multiple-covariate distance sampling (MCDS) models within DISTANCE 6.0, which also examined alternative continuous, quadratic or categorical formulations (SOM, "Methods" section). Those detectability covariates supported by the best MCDS model [lowest Akaike information criterion (AIC)] were subsequently included in distance models used to estimate houbara density and 
Table 1 Candidate environmental and landscape context variables for models of male Asian Houbara abundance

\begin{tabular}{|c|c|c|}
\hline Variable name & Description & Type of data \\
\hline \multicolumn{3}{|c|}{ Detectability variables } \\
\hline Date & Date on which a count was conducted, first day $=24$ March & Continuous \\
\hline Visit & First or second visit to a point count & Categorical \\
\hline Time categorical & Time of the count $(1=$ morning, $2=$ afternoon $)$ & Categorical \\
\hline Time continuous & Time of the count (minutes after sunrise/before sunset) & Continuous \\
\hline Time $^{2}$ & Time of the count (squared) & Categorical \\
\hline Time $^{3}$ & Time of the count (cubed) & Categorical \\
\hline Wind & $\begin{array}{l}\text { Estimated wind strength during point count/Beaufort scale equivalent }(1 / 0=\text { no wind, } \\
2 / 1-2=\text { weak, } 3 / 3-4=\text { medium, } 4 / 5-6=\text { strong })\end{array}$ & Categorical \\
\hline Shrub height & $\begin{array}{l}\text { Mean height of all shrubs [cm; } n=28 \text { species, excluding the very short Salsola } \\
\text { gemmascens and Nanophyton erinaceum (mean }<12 \mathrm{~cm} \text { ), pooled per point count] }\end{array}$ & Continuous \\
\hline \multicolumn{3}{|l|}{ Land-use variables } \\
\hline Sheep density & $\begin{array}{l}\text { Mean density (individuals } \mathrm{km}^{-2} \text { ) extracted from 2-km radius buffers around point count } \\
\text { location }\end{array}$ & Continuous \\
\hline \multicolumn{3}{|l|}{ Habitat variables } \\
\hline Shrub height & As above & Continuous \\
\hline Substrate PCA1 & $\begin{array}{l}\text { Sample score from first axis of unrotated principal component analysis (PCA) } \\
\text { performed in PRIMER } 6.1 .10 \text { on correlation matrix of unconsolidated sand, } \\
\text { consolidated sand, gravel and clay cover }\end{array}$ & Continuous \\
\hline Substrate PCA2 & Sample score from second PCA axis & Continuous \\
\hline Shrub MDS1 & $\begin{array}{l}\text { Sample score of multidimensional scaling (MDS) ordination of composition of shrubs } \\
\text { based on } 4 \times 50 \text {-m line intercepts from each of } 817 \text { locations (2012-2014 data), } \\
\text { performed in PRIMER 6.1.10 }\end{array}$ & Continuous \\
\hline Shrub MDS2 & Sample score from second MDS axis & Continuous \\
\hline DEM SD & $\begin{array}{l}\text { Landscape rugosity-standard deviation values of elevation (m), extracted from 2-km } \\
\text { buffers around point counts (ASTER GDEM V2, horizontal resolution } 30 \mathrm{~m} \text {, vertical } \\
\text { resolution one meter) }\end{array}$ & Continuous \\
\hline Shrub assemblage & $\begin{array}{l}\text { Sample locations overlaid on mapped distribution of five shrub assemblages, classified } \\
\text { by cluster analysis of shrub frequency at } 817 \text { locations (2012-2014 data) }\end{array}$ & Categorical \\
\hline GLOBCOVER & $\begin{array}{l}\text { The proportion of grid squares from three aggregate global land cover (GLC 2000, } \\
\text { approx. } 700 \mathrm{~m} \times 900 \mathrm{~m} \text { spatial resolution) classes within 2-km buffers around point } \\
\text { count locations: Globcover: vegetation (highest \% grids classified as herbaceous and } \\
\text { shrub cover); Globcover: consol. (highest \% of consolidated sand); Globcover: } \\
\text { unconsol (highest \% of unconsolidated sand) and Globcover: diversity (Simpson's } \\
\text { Diversity Index, adjusted to equitability) }\end{array}$ & Categorical \\
\hline
\end{tabular}

population size and in subsequent multivariate species habitat models.

The density of male houbara in each of the five shrub assemblages was estimated by MCDS models that incorporated supported detectability variables, stratifying encounter rate and density by shrub assemblage, and the total number of males was estimated as the area-weighted mean of assemblage-specific estimates.

\section{Habitat and land use variables}

To examine the potential influence of habitat, landform and land use on houbara abundance, six habitat variables (landscape rugosity, remote sensed land cover, and field derived measures of soil [substrate] type, shrub vegetation composition and structure) and one anthropogenic variable (sheep density) were considered (Table 1). The mean seasonal sheep density around each point was extracted from an interpolated density surface based on multiple distance transects, rather than visit-specific measures that would be affected by sampling error relative to daily flock movements. Field measures of substrate, shrub composition, assemblage class and structure taken around each point count were used in model calibration. Similar measures were taken at an additional 586 sampling locations across the study area, allowing interpolation to calculate assemblage extent (for habitat-area weighted population estimates) and resampling when predicting abundance using multivariate habitat models.

Shrub species composition and structure measurements were taken along four 50-m line intercepts located $500 \mathrm{~m}$ from each of the 231 point count locations during 16 May- 
6 June 2013, and from an additional 586 locations sampled during May-June 2012, 2013 and 2014 (for details on sampling, please see SOM, "Introduction" section). Pooled line intercept data were used to calculate average shrub height (considered as a measure of concealment and potentially also the availability of invertebrate prey). Substrate cover, i.e. clay, consolidated sand, drifting sand and gravel, was measured in one $2 \mathrm{~m} \times 2 \mathrm{~m}$-quadrat per line intercept and pooled means were reduced to two orthogonal variables, substrate PCA1 and substrate PCA2 (Table 1), by unrotated principal component analysis performed on the correlation matrix in PRIMER 6.1.10. Shrub species were identified following Gintzburger et al. (2003); further sampling details are provided in 'Supplementary materials' (SOM, "Introduction" section). Shrub composition was considered separately in terms of classification of five categorical shrub assemblage (by cluster analysis, SOM, "Introduction" section), or as two uncorrelated ordination axes obtained by multidimensional scaling (MDS): shrub MDS1 and shrub MDS2 (SOM, Fig.S1). Shrub assemblage, shrub structure and substrate were interpolated (using the inverse distance weighted tool in ArcMap 10.1) across the study area from data recorded at all 817 sampling locations. As the habitat and landscape context selected by the most distant birds affect numbers seen within $1.4 \mathrm{~km}$ of a point count, sheep density, rugosity and land cover were extracted from a buffer of $2 \mathrm{~km}$ around the point.

To test if freely available remotely sensed land cover classification provided meaningful models of abundance, thus removing the need for detailed field measures, we used global land cover data (GLC 2000; Bartholomé and Belward 2005), with proportionate cover of each of three aggregate classes (see Table 1 for definitions) extracted within a 2-km buffer around points using ArcMap 10.1. Land cover diversity within each buffer was calculated as Simpson's diversity index, $D$ (Simpson 1949), adjusted to equitability (evenness), $E_{D}$ following:

$E_{D}=\frac{D}{D_{\max }}=\frac{1}{S \sum_{i=1}^{3} p_{i}^{2}}$

where $D_{\max }$ is the maximum value $D$ could assume if the three land cover classes were evenly distributed and $p_{i}$ the proportion of the $i$ th class.

Landscape rugosity (DEM SD) was obtained from ASTER GDEM V2 (NASA 2011), with low and high DEM $S D$ values indicating flat and undulating/dissected terrain, respectively.

Sheep were counted along a total of $9475-\mathrm{km}$ transects between 26 March and 31 May 2013 from a vehicle driven at $30-50 \mathrm{~km} / \mathrm{h}$ along trackways, with a minimum of $2 \mathrm{~km}$ between consecutive transects to avoid spatio-temporal autocorrelation. Sheep are walked across the desert all day, excluding sunrise and sunset, when they are herded to or from camps; so counts were conducted between 08:00 and 17:00. For each flock, numbers were counted (using binoculars) and the perpendicular distance to the flock centre, following Buckland et al. (2001), was measured by rangefinder. Sheep density was estimated by distance analysis and an interpolated surface was created (SOM, "Results" section).

\section{Multivariate models of houbara distribution}

Habitat, land cover, landform and land use effects on visitspecific counts of male houbara were examined by random intercept generalised linear mixed models (GLMMs) with Poisson error, constructed in R (Ime4 package), allowing detectability of covariates supported by distance analysis to be incorporated as fixed effects and including point identity (ID) as a random effect to control for repeat visits. However, to extrapolate relative abundance across the study area, we also constructed separate generalised linear models (GLMs) of maximum count across the two visits (as the random effect of point ID cannot be extrapolated for unsampled areas). Binomial mixture models were considered inappropriate as their assumption of a static population between resampling events (Royle 2004) was probably violated (SOM, "Discussion" section). Strong intercorrelation, defined as $r>0.5$, following Freckleton (2002), was found between shrub MDS1 and substrate PCA1 $(r=-0.645)$ and between shrub MDS1 and shrub height $(r=-0.580)$. Therefore, physical vegetation and substrate measures were considered separately from shrub composition data for analysis, resulting in four sets of environmental models: (1) 'Vegetation structure': shrub height + substrate PCA1 + substrate PCA2; (2) 'Shrub assemblage': shrub assemblage; (3) 'Shrub MDS': shrub MDS1 + shrub MDS2; (4) 'GLOBCOVER' (four continuous variables). All environmental models also considered the effect of landscape rugosity and sheep density.

For model selection multi-model inference (MMI), an information theoretic framework, was applied to each of the four sets of candidate models, following Burnham and Anderson (2002), using the 'MuMIn' package in R (Barton 2013). Model-averaged parameter estimates, their unconditional errors and the relative support for each variable (relative variable importance [RVI], scale 0-1) were calculated across the $95 \%$ model confidence set. However, variables which have no effect accumulate weight through their presence in models that gain support by their inclusion of important variables. Therefore, to assess the relative importance of candidate predictors, we examined the $95 \%$ interval of RVI distribution of a simulated random null variable $($ mean $=1, \mathrm{SD}=1)$ iterated across $1000 \mathrm{MMI}$ iterations, following Boughey et al. (2011). Candidate 
variables with an RVI beyond the $95 \%$ null distribution and with a model average coefficient $95 \%$ confidence limit (calculated from unconditional standard errors) not spanning zero were considered to have support (following Boughey et al. 2011). All models were run in R 3.0.2 ( $R$ Core Team 2013). Potential spatial autocorrelation in model-averaged residuals was examined by Moran's I in R (Graf et al. 2005).

The mapped relative distribution predicted by MMI species-habitat models was examined by overlaying a grid (resolution $1836 \mathrm{~m} \times 1836 \mathrm{~m}$, cell area $=3.371 \mathrm{~km}^{2}$ ) on the study area, providing a grid cell area equal to that encompassed by the estimated effective detection radius (EDR; $1036 \mathrm{~m}$ ) around point counts (see "Results"). Values of each variable were extracted from each cell and numbers were predicted from the model-averaged $95 \%$ confidence subset of candidate GLMs for each model set. Temporal transferability of models was examined by repeating surveys twice at 140 of the points in 2014 and inspecting the correlation $\left(R^{2}\right)$ between predicted (abundance values extracted from grid cells intersecting point count locations) and observed (maximum number of birds per point count) abundance.

\section{Results}

During 2013, at point count locations $(n=231) 317$ individuals or small groups of houbara were recorded, comprising 321 adults and 15 juveniles. Of the adults that could be sexed $(n=311,98 \%)$, $94 \%$ were males; females were substantially under-recorded as they are far more cryptic than males in the breeding season, with many incubating during the survey period (Burnside, unpublished data). Observations of females were, therefore, excluded and unsexed birds and males were pooled for subsequent analysis, adjusting for the estimated proportion of males among unsexed birds in density estimates.

\section{Habitat gradients}

A total of 65,939 shrubs were identified and measured along $155.1 \mathrm{~km}$ of walked line intercepts at 817 sampling locations (mean of 46.8 shrubs per composite sample, $\mathrm{SD}=34.2$, range $0-233$ shrubs). Mean shrub height varied from over $45 \mathrm{~cm}$ in the west and south, mainly in Astragalus and Calligonum, to under $30 \mathrm{~cm}$ in Artemisia, Salsola rigida and $S$. arbuscula assemblages (SOM, Fig. S2d).

The first substrate component (Substrate PCl) explained $59.2 \%$ of the variance and represented a gradient from greater cover of clay to greater cover of consolidated sand; gravel and drifting sand had negligible loadings on this component. The second component (Substrate PC2) explained a further $20.4 \%$ of the variance, with a gradient from gravel (low values) to drifting sand (high values; SOM, Fig. S3). Dominant substrate types differed between shrub assemblages, with $>50 \%$ cover of clay in both Artemisia and Salsola rigida, $>75 \%$ cover of consolidated sand in Astragalus and the highest cover of drifting sand (18\%) in Calligonum (SOM, Fig. S4).

Sheep density differed among shrub assemblages $\left(F_{4,761}=32.5, p=0.001\right.$, all pair-wise Tukey $\left.p<0.05\right)$, being highest in Calligonum (mean 40.0 individuals $\mathrm{km}^{-2} \pm 2.1[\mathrm{SE}]$ ), similar between Astragalus and Artemisia $(31.5 \pm 1.5 ; 24.7 \pm 2.2$, Tukey $\mathrm{p}>0.05)$ and lowest in Salsola arbuscula $(19.4 \pm 1.3)$ and $S$. rigida (14.4 \pm 1.5 ; SOM Fig. S2a), but variation within shrub assemblages was high and overall variance explained by shrub assemblage was low (GLM, $\left.R^{2}=0.17\right)$, allowing independent effects to be tested.

\section{Detectability covariates and estimates of male houbara density}

In distance analysis of houbara observations, half-normal functions with cosine adjustments provided the best fit, with a mean EDR of $1036 \mathrm{~m}$ (95\% confidence interval [CI]; 985-1091). A 400-m wide trough in radial distance suggests that some houbara near to the observers either crouched and remained undetected, or (more likely) sneaked off and were subsequently detected when over $400 \mathrm{~m}$ away (Fig. 2). The best MCDS model included visit (season effect) and time categorical $(\mathrm{am} / \mathrm{pm})$ covariates, which improved the model fit $(\triangle \mathrm{AICc}=-5.6)$ relative to a null model. The three closest competing MCDS models also included combinations of both season (visit or date) and time of day (time categorical, or time + time $^{2}$ ) and provided similar density estimates and CIs; these represent

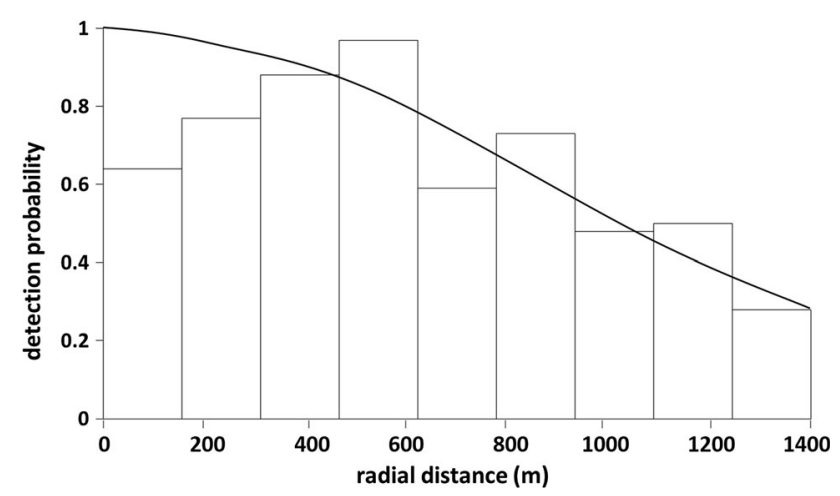

Fig. 2 Probability of detection of male houbara on point counts, based on the best MCDS model (including visit and time categorical as detectability covariates), with half-normal detection function (with cosine adjustment) fitted to visit-specific count data, truncated at 1400-m distance from the observer 
Table 2 Comparison of density and population estimates of male Asian Houbara on point counts (including observations of unsexed birds and adjusting for proportion of males among sexed birds) from conventional distance sampling (CDS) models (not including

\begin{tabular}{|c|c|c|c|c|}
\hline Model (strata) & $\mathrm{AICc}$ & $\begin{array}{l}\text { Goodness of fit } \\
\text { (Cramer von Mises) }\end{array}$ & $\begin{array}{l}\text { Density estimate } \\
\text { (birds } / \mathrm{km}^{2}, 95 \% \mathrm{CI} \text { ) }\end{array}$ & $\begin{array}{l}\text { Total population estimate } \\
\text { (birds, } 95 \% \mathrm{CI} \text { ) }\end{array}$ \\
\hline CDS (null model) & 3109.3 & 0.0798 & $0.135(0.111-0.164)$ & 1886 (1698-2089) \\
\hline MSDC & 3103.7 & 0.0618 & $0.140(0.126-0.155)$ & \\
\hline MSDC (5 Strata) & 3103.7 & 0.0618 & & 1824 (1645-2030) \\
\hline Artemisia & & & $0.090(0.081-0.100)$ & $243(218-270)$ \\
\hline Astragalus & & & $0.150(0.136-0.167)$ & $532(483-594)$ \\
\hline Calligonum & & & $0.041(0.037-0.046)$ & $61(55-69)$ \\
\hline Salsola arbuscula & & & $0.146(0.131-0.162)$ & $529(477-588)$ \\
\hline Salsola rigida & & & $0.223(0.200-0.248)$ & $457(410-509)$ \\
\hline
\end{tabular}

For all models, observations were truncated at a $1.4-\mathrm{km}$ distance

alternative formulation of the same detectability effects (SOM, Table S1,A). Therefore visit and time categorical were included in subsequent distance models of houbara density and as fixed effects in all multivariate abundancehabitat models. Three models that also incorporated shrub height and wind were within two AICc units of the best model but addition of these covariates to the best model did not improve the model fit or alter the detection function (maximum EDR change $1 \mathrm{~m}$ ) or density estimate (SOM, Table S1,B); thus, there is no evidence that they affected detectability. As shrub height did not affect detectability it was included as a candidate variable in subsequent multivariate models of habitat association.

Inclusion of detectability covariates improved the model fit and marginally increased its precision (Table 2). In 2013, mean male density across the study area was $0.14 \mathrm{~km}^{-2}$ (95\% CI; 0.12-0.15; unstratified MCDS model). Stratified by shrub assemblage, density was highest in S. rigida [0.22 males km $\mathrm{km}^{-2}$ (95\% CI 0.20-0.25)]; lower but similar between Astragalus and S. arbuscula [0.15 (0.14-0.17) and $0.14(0.13-0.16)$ ]; lower again in Artemisia [0.09 (0.08-0.10)]; and lowest in Calligonum [0.04 (0.04-0.05)]. The total number of males was similar when estimated with [1824 (95\% CI 1645-2030)] and without [1886 (95\% CI 1698-2089)] stratification by shrub assemblage, as sampling intensity was largely proportionate to assemblage extent.

\section{Houbara habitat and land use associations}

Residuals of model-averaged GLMs and GLMMs were not spatially auto-correlated for all four model sets (all Moran's $I<0.01)$.

In MMI of the 'Vegetation structure' model set, effects of shrub height, substrate PCA2 and DEM SD were all strongly supported (Fig. 3a), with greater numbers of males detectability covariates) and alternate unstratified and stratified multi-covariate distance sampling (MCDS) models that included visit and time categorical detectability covariates in areas with perennial shrubs of lower height, less cover of drifting sand relative to gravel and in flatter areas. The 'Shrub assemblage' MMI showed strong support only for effects of shrub assemblage (Fig. 3b), suggesting male numbers were highest in S. rigida, lower in Artemisia, Astragalus and S. arbuscula and lowest in Calligonum (see Fig. 3 text for parameter estimates), consistent with results from stratified MCDS (Table 2). The 'Shrub MDS' MMI showed support for both shrub MDS1 and shrub MDS2, but the positive loading on MDS1 of both preferred (Astragalus) and less preferred (Calligonum) shrub species (SOM, Fig. S1) makes interpretation problematic (Fig. 3c). No candidate variables were supported within the 'GLOBCOVER' model set, with all RVIs within the $95 \%$ null interval and CIs spanning zero (Fig. 3d), precluding its use in spatial extrapolation. Irrespective of the vegetation classification used, there was no support for any effect of sheep density on male houbara density.

\section{Abundance estimates}

Relative abundance mapped and extrapolated from the 'Vegetation structure' GLM set had the strongest correspondence with calibration data from both 2013 and 2014 $\left(R^{2}=0.22\right.$ and 0.15 respectively; Fig. 4$)$, with a weak negative relation between observed and predicted data for 'Shrub assemblage' $\left(R^{2}=0.01,0.006\right)$ and 'Shrub MDS' model sets $\left(R^{2}=0.04,0.08\right.$; SOM, Fig.S5).

\section{Discussion}

Within the southern Kyzylkum Desert, the abundance of male houbara during the breeding season is higher in areas of flatter terrain with shorter shrub vegetation, characteristic of areas with more gravel, factors all probably 

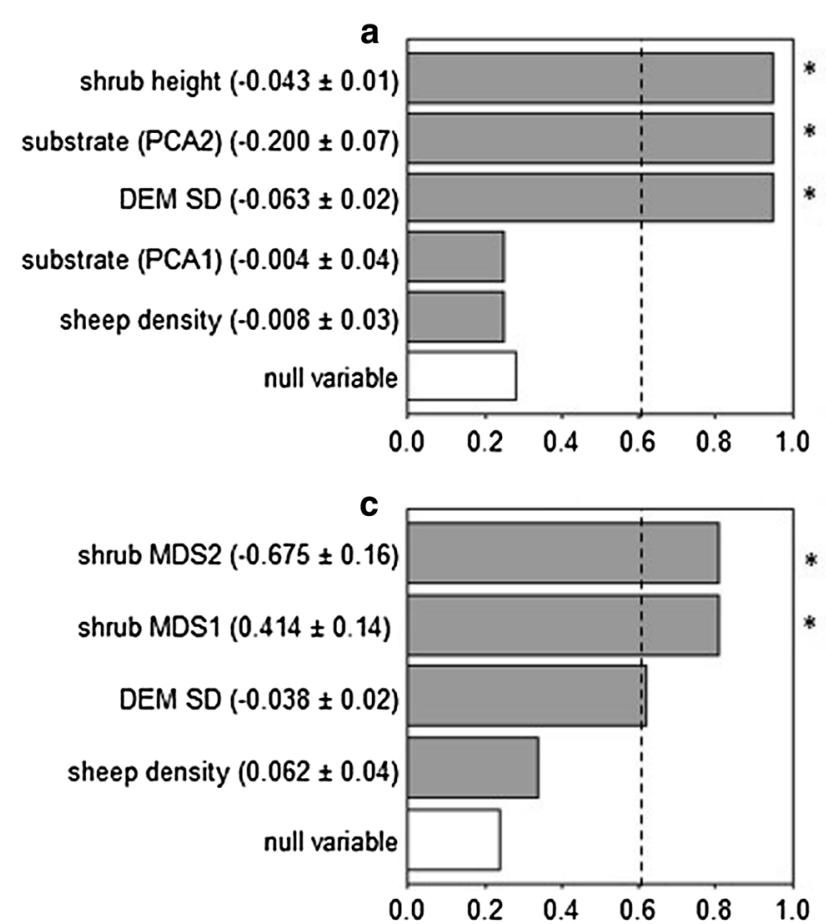

Relative variable importance ( $\sum$ Akaike Weights)
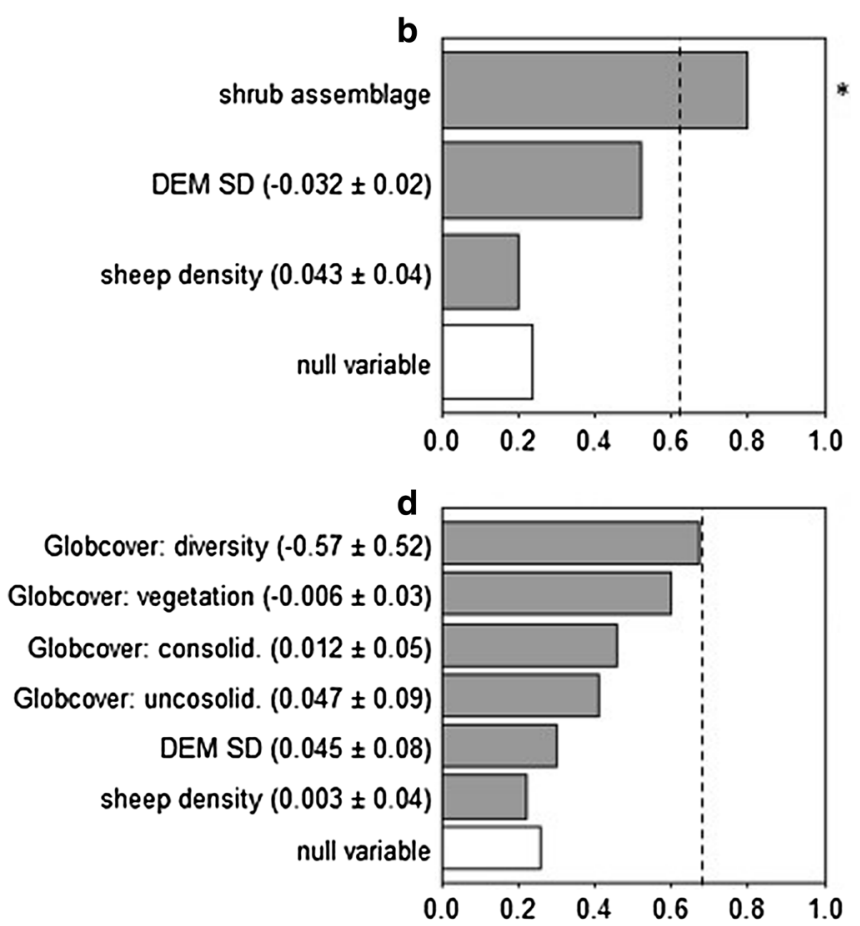

Fig. 3 Relative variable importance (RVI) and model-averaged coefficients \pm SE for each predictor, calculated across each of four $95 \%$ confidence sets of candidate generalised linear mixed models (GLMM) considering a Vegetation structure; b Shrub assemblage [five categories: $S$. rigida (mean coefficient $0.528 \pm 0.31 \mathrm{SE}$ ), $S$. arbuscula $(-0.166 \pm 0.29)$, Calligonum $(-0.906 \pm 0.43)$, Astragalus (0.094 \pm 0.31$)$, referenced to Artemisia]; c Shrub MDS;

consistent with display visibility. Male houbara occurred at highest density in areas characterised by Salsola rigida, intermediate densities in Astragalus or S. arbuscula and at lower density in Calligonum, but shrub structure was a better predictor of abundance than shrub composition. Sheep density did not affect the abundance of male houbara within the study area.

\section{Habitat effects}

The increasing prevalence of males in shorter vegetation and flatter terrain may have several explanations, not necessarily mutually exclusive. Probably most important are the needs to be visible to females and to have enough open ground in which to conduct their display, which involves a fast run, sometimes for long distances (Gaucher et al. 1996). Apparent selection for gravel is likely a consequence of the sparse short-statured shrub vegetation in such areas. Moreover, an unhindered view of the surrounding terrain allows the detection of both predators and approaching/passing females, but it is also possible that flat terrain also reduces the locomotion cost for these large d GLOBCOVER. All models also included point ID as a random effect and visit (first or second) and time (morning or evening) as fixed effects (RVI = 1, not shown). See Table 1 for definition of predictors. Unfilled bars and the vertical dashed line show the median and $95 \%$ limit of RVI of a random null variable (across $1000 \mathrm{MMI}$ iterations), respectively; an asterisk denotes strongly supported predictors

cursorial birds. The combination of medium to short shrubs and flat terrain seems to be the most favourable habitat for male houbara in the study area.

The probability of occurrence of African houbara in flat terrain (areas with slope of the terrain $<15 \%$ ) has been reported for a breeding population in Lanzarote, Canary Islands (Carrascal et al. 2006). However, this is the first study to show how vertical vegetation structure can influence houbara numbers at a landscape scale. With the exception of Carrascal et al. (2008), other studies have not considered shrub height, possibly due to the huge effort needed to robustly collect such data (van Heezik and Seddon 1999; Yang et al. 2002a; Hingrat et al. 2008; Chammem et al. 2012). A study by Carrascal et al. (2008) did not find an influence of shrub height; however, this compared mean shrub height at presence versus absence sites across a range of suitable and unsuitable habitats, dominated by short vegetation and, therefore, other features, such as sandy substrate, were more influential at this scale of analysis. Studies that assessed houbara habitat use without sex differentiation, through sampling tracks or telemetry locations (Combreau and Smith 1997; Launay 


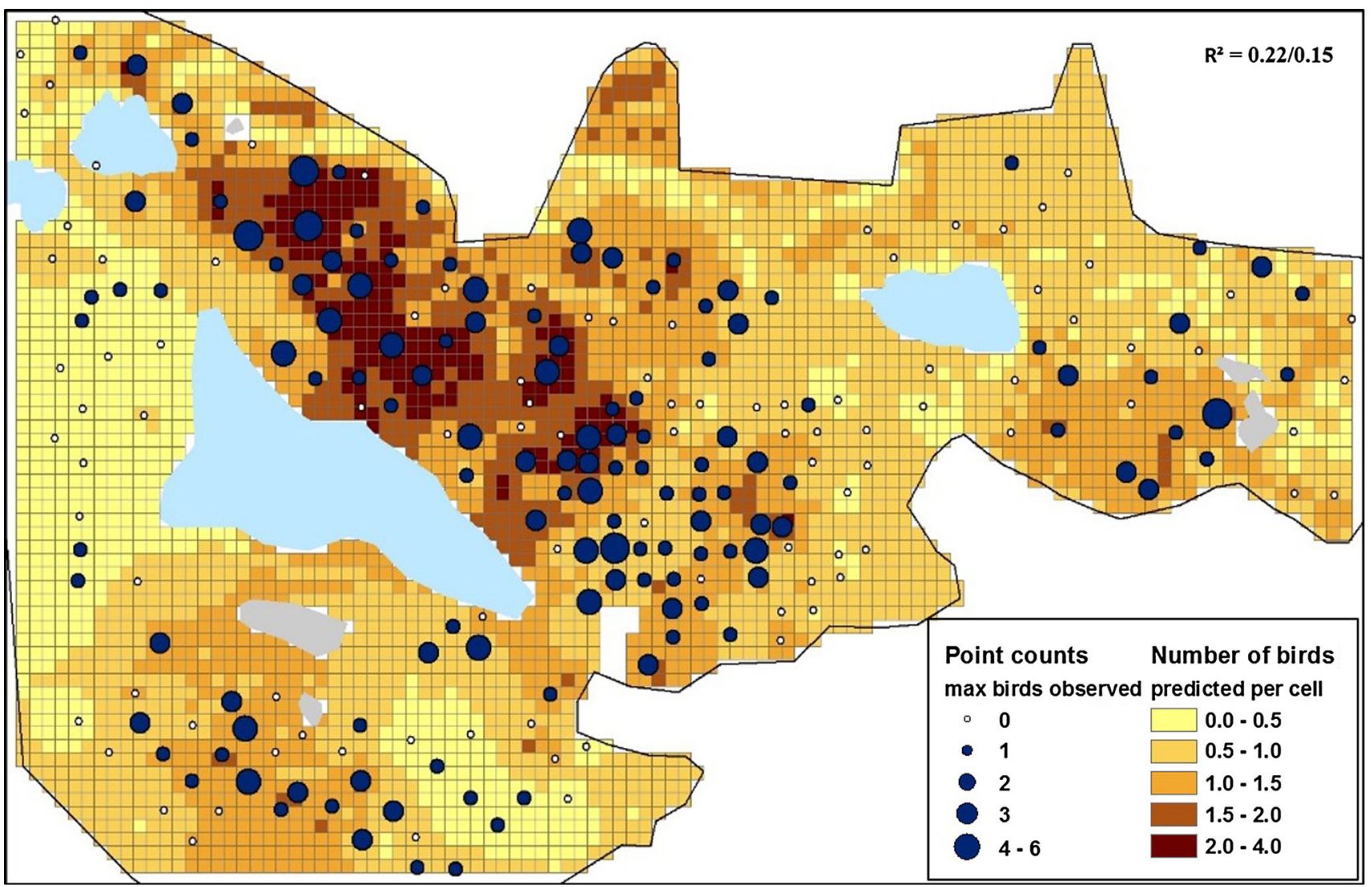

Fig. 4 Distribution of male Asian Houbara density across the Bukhara District in Uzbekistan predicted from the averaged 'Vegetation structure' MMI model set, overlaid with the observed maximum numbers seen during point counts in $2013 . R^{2}$ indicates

et al. 1997b), are not comparable to ours as habitat use is expected to differ between males and females (Hingrat et al. 2007).

Male houbara densities differed among the five shrub assemblages. Sparse short halophytic vegetation dominated by Salsola rigida supported the highest density (Table 2). Lower densities (similar to each other) occurred in vegetation dominated by Astragalus villosissimus and Salsola arbuscula. Owing to the large area they occupy $\left(=7682 \mathrm{~km}^{2}\right)$, the latter two assemblages together hold over $50 \%$ of all males estimated for the Bukhara study area. Calligonum and Artemisia shrub assemblages supported lower densities of male houbara. Calligonum comprises a rich diversity of shrubs on drifting sand, including Calligonum sp., Convolvulus sp. and Astragalus villosissimus. The main limiting factor for male houbara here is most likely the mean height of vegetation $(>0.5 \mathrm{~m})$, which presumably impairs visibility of their display. Artemisia shrub assemblages (dominated by A. diffusa) prevail in the most elevated parts of the study area, but, although plants of this genus are palatable to houbara (Gubin 2004), they are not thought to be preferred food during the breeding correspondence of predicted abundance with observed point count maxima in the model calibration year (2013) and subsequent year (2014)

season (J. Al-Khaili personal communication). Also, owing to the uniform low height and, hence, poor concealment by the vegetation, these areas might be less suitable for nesting females. If the houbara 'exploded lek' system follows a 'hotspot' model (Beehler and Foster 1988; i.e. males lek where females congregate for resources), it is possible that lower suitability of both Calligonum and Artemisia assemblages for breeding females may affect male densities. Both MDS predictors were supported, indicating that density of male houbara was affected by shrub species composition, but neither shrub assemblage nor MDS gave as good an explanation of male distribution as shrub structure. This suggests males primarily respond to shrub structure, for which composition is a proxy, rather than to systematic differences in resource availability among shrub assemblages.

\section{Land use effects}

Our evidence that at landscape scales male houbara do not avoid areas with greater sheep densities (highest mean per point count $>100$ individuals $\mathrm{km}^{-2}$ ) confirms an earlier 
study (Koshkin et al. 2014) and agrees with findings on African Houbara in Tunisia (Chammem et al. 2012) but not from Morocco (Le Cuziat et al. 2005a, b). The discrepancy with Morocco perhaps reflects differences between rangeland systems. In Morocco (Le Cuziat et al. 2005b) and in Tunisia (Combreau personal communication), sheep and goats grazed desert adjacent to wells all year round, thus permanently affecting vegetation, whereas in the more strongly seasonal pastoralism of Uzbekistan grazing is predominantly confined to the spring and early summer months. Such seasonal pastoralism, which is probably the most important and widespread land use within the entire range of the Asian Houbara, appears to have no negative impact on either Chlamydotis species or their habitat (Gamoun 2014; Koshkin et al. 2014), at least at the range of sheep densities examined. However, caution is needed on this issue, as disturbance of nesting females and incidental nest destruction by livestock and egg-taking by shepherds, together suggested to be the main threats for a population in Israel (Lavee 1988), cannot be discounted.

\section{Houbara population estimate}

Our estimate of 0.14 male houbara $\mathrm{km}^{-2}(95 \% \mathrm{CI}$ $0.12-0.15)$ suggests $0.28(0.24-0.30)$ adult houbara overall for the study area in Uzbekistan, if an equal sex ratio can be assumed (following Combreau et al. 2002). However, comparison with densities estimated for other Asian Houbara populations is problematic. Most recent studies used driven transects (Tourenq et al. 2004, 2005; Gubin 2008; Riou et al. 2011) and each had methodological drawbacks. In Koshkin et al. (2014) point counts were found to perform better than transects, at least in the conditions of the southern Kyzylkum. Gubin (2008) based multi-annual estimates for several areas in south-western Kazakhstan on numbers of individuals recorded along driven transects within a 200-m survey strip (range of 0.01-0.24 birds/ $\mathrm{km}^{2}$ ); this may indicate relative abundance among areas, but as detectability was unknown it is not possible to account for undetected birds to estimate density. Although Riou et al. (2011) and Tourenq et al. (2004, 2005) used distance analysis, distance measurements were not taken and the effective strip width (ESW) is not reported; also, analysis pooled across regions with differing relative abundance resulting in wide uncertainty, and timing and sex composition are not reported. Although more females are detected during driven transects (30\% of adult birds) than on point counts ( $7 \%$; Koshkin et al. 2014), densities estimated by Riou et al. (2011) and Tourenq et al. (2004, 2005) will have been underestimated to an unknown extent. Depending on timing, estimates may lie somewhere between an estimate of male numbers (comparable to our male estimate) for survey during incubation (when females are infrequently observed even on driven transects) to an estimate comprising both males and females during brood rearing/post-nesting, closer to, but still likely underestimating, total numbers.

With these considerations, our estimate of male houbara density appears substantially greater than breeding densities observed in Oman [average across 3 years, 0.03 birds $\mathrm{km}^{-2}$ (inter-annual range $0.01-0.05$ birds $\mathrm{km}^{-2}$ ); Tourenq et al. (2005)] and in three regions of Kazakhstan, each averaged across three 3-year periods (Riou et al. 2011): 'Kyzylkum', 0.05 birds $\mathrm{km}^{-2}$ (inter-period range 0.04-0.06); 'Karakum', $0.02(0.01-0.02)$ and 'North east' 0.01 (0.008-0.02); but comparable to densities in two other regions of Kazakhstan: 'Betpak-Dala' of 0.11 birds $\mathrm{km}^{-2}$ (inter-period range 0.06-0.15) and 'Balkash', 0.10 (0.06-0.15; Riou et al. 2011) and in China [average across five years 0.12 birds $\mathrm{km}^{-2}$; (inter-annual range 0.05-0.20); Tourenq et al. (2005)].

\section{Analytical challenges}

Inclusion of a random null variable following Boughey et al. (2011) clarified the interpretation of variable importance in cases when model selection ranked a variable high based on the sum of AIC weights. We used GLMs to predict and map abundances - an approach widely used and tested in ecological studies (Segurado and Araújo 2004; Elith and Graham 2009; Oppel et al. 2012). Predictors within the 'GLOBCOVER' model set failed to explain abundance of male houbara, probably owing to coarse resolution (approx. $700 \mathrm{~m} \times 900 \mathrm{~m}$ ) and potential lower ability of the GLC 2000 dataset to meaningfully classify subtle differences among desert vegetation and substrates. Thus, freely available data could not substitute for detailed field measurements. A massive sampling effort was needed for the extrapolation of field measurements of shrub height and composition across the study area as well for the stratification by shrub assemblages of distance estimates. This enabled comparison of densities among plant assemblages, but did not substantially improve precision of the overall estimate, with $95 \%$ CIs only $1.5 \%$ narrower than those of the unstratified pooled estimate (Table 2), presumably due to proportionate sampling relative to assemblage extent. Maps of houbara male abundance based on the three remaining model sets showed different patterns, with 'Vegetation structure' giving the strongest agreement with the validation set.

\section{Conclusion}

This study is an initial step towards an understanding of the habitat requirements of and constraints on Asian Houbara populations on their breeding grounds, and is the first time 
that abundance of the species has been linked to particular plant assemblages. The more than two-fold difference in density between Salsola- and Artemisia-dominated habitats, and five-fold lower density in Calligonum habitats on unconsolidated sands, show the risks of extrapolating range-wide population estimates from local estimates of density, without accounting for desert shrub/substrate composition. Habitats selected by males are likely to maximise the visibility and performance of their displays, as in male Great Bustards Otis tarda (Moreira et al. 2004) and male Bengal Floricans Houbaropsis bengalensis (Gray et al. 2009). However, the possibility remains that lower densities in some shrub assemblages reflect a lower suitability of these habitats for females, and, thus, a reduced attractiveness for males to congregate in such landscapes. Further work is required to determine what conditions the far more elusive females need for breeding, as their habitat and landscape preferences may differ somewhat from those of males (Hingrat et al. 2007), as in Bengal Florican (Gray et al. 2009). The southern Kyzylkum Desert is increasingly being targeted for energy (gas and oil) exploration (personal observation), and conservation biologists need a robust evidence base to ensure the best management for Uzbekistan's houbaras as their habitat experiences disruptions associated with economic development and infrastructural encroachment. As more information accumulates it will become possible to prioritise particular habitats for protection; evidence presented here suggests higher priority should be given to Salsola- and Astragalus-dominated areas than to Calligonum habitats on unconsolidated sands.

Acknowledgments This study was funded by the Ahmed bin Zayed Charitable Foundation, and permission to conduct it was given by the State Committee for Nature Conservation of the Republic of Uzbekistan. We thank Vladimir Terentyev, Lizzie Grayshon, Judit Mateos, Sofie Forsstrom and Charlotte Packman for contributions to data collection; Prof. Antonina Butnik and Dr. Toshpulot Rajabov for validation of our identification of desert shrubs and Olivier Combreau and an anonymous reviewer for helpful comments on an earlier version of the paper.

Open Access This article is distributed under the terms of the Creative Commons Attribution 4.0 International License (http://crea tivecommons.org/licenses/by/4.0/), which permits unrestricted use, distribution, and reproduction in any medium, provided you give appropriate credit to the original author(s) and the source, provide a link to the Creative Commons license, and indicate if changes were made.

\section{References}

Aghainajafi-Zadeh S, Hemami MR, Karami M, Dolman PM (2010) Wintering habitat use by houbara bustard (Chlamydotis macqueenii) in steppes of Harat, central Iran. J Arid Environ 74:912-917
Aghanajafizadeh S, Hemami MR, Naderi G, Heydari F (2012) Estimation of Houbara Bustard, Chlamydotis macqueenii, population density in the central Iranian steppes. Zool Middle East $56: 3-8$

Bartholomé E, Belward AS (2005) GLC2000: a new approach to global land cover mapping from Earth observation data. Int $\mathbf{J}$ Remote Sens 26:1959-1977

Barton K (2013) MuMIn: multi-model inference. R package version 1.15.1. http://cran.r-project.org/web/packages/MuMIn/index. html

Beehler BM, Foster MS (1988) Hotshots, hotspots, and female preference in the organization of lek mating systems. Am Nat 131:203-219

BirdLife International (2015) Species factsheet: Chlamydotis macqueenii. http://www.birdlife.org. Accessed on 31 July 2015

Boughey KL, Lake IR, Haysom KA, Dolman PM (2011) Effects of landscape-scale broadleaved woodland configuration and extent on roost location for six bat species across the UK. Biol Conserv 144:2300-2310

Buckland ST, Anderson DR, Burnham KP, Laake JL, Borchers DL, Thomas L (2001) Introduction to distance sampling: estimating abundance of biological populations. Oxford University Press, Oxford

Burnham KP, Anderson DR (eds) (2002) Model selection and multimodel inference. A practical information-theoretic approach. Springer, New York

Carrascal LM, Seoane J, Palomino D, Alonso CL (2006) Habitat preferences, population size and demographic trends of houbara bustard Chlamydotis undulata in Lanzarote and La Graciosa (Canary Islands). Ardeola 53:251-269

Carrascal LM, Palomino D, Seoane J, Alonso CL (2008) Habitat use and population density of the houbara bustard Chlamydotis undulata in Fuerteventura (Canary Islands). Afr J Ecol 46:291-302

Chammem M, Selmi S, Khorchani T, Nouira S (2012) Using a capture-recapture approach for modelling the detectability and distribution of houbara bustard in southern Tunisia. Bird Conserv Int 22:288-298

Chargé R, Sorci G, Saint Jalme M, Lesobre L, Hingrat Y, Lacroix F, Teplitsky C (2014) Does recognized genetic management in supportive breeding prevent genetic changes in life-history traits? Evol Appl 7:521-532

Combreau O, Launay F (1996) Activity rhythms of houbara bustards (Chlamydotis undulata macqueenii) in relation to some abiotic factors. J Arid Environ 33:463-472

Combreau O, Smith TR (1997) Summer habitat selection by houbara bustards introduced in central Saudi Arabia. J Arid Environ 36:149-160

Combreau O, Smith TR (1998) Release techniques and predation in the introduction of Houbara bustards in Saudi Arabia. Biol Conserv 84:147-155

Combreau O, Launay F, Lawrence M (2001) An assessment of annual mortality rates in adult-sized migrant houbara bustards (Chlamydotis undulata macqueenii). Anim Conserv 4:133-141

Combreau O, Qiao J, Lawrence M, Gao X, Yao J, Yang W, Launay F (2002) Breeding success in a houbara bustard Chlamydotis [undulata] macqueenii population on the eastern fringe of the Jungar Basin, People's Republic of China. Ibis 144:E45-E56

Elith J, Graham CH (2009) Do they? How do they? WHY do they differ? On finding reasons for differing performances of species distribution models. Ecography 32:66-77

Freckleton RP (2002) On the misuse of residuals in ecology: regression of residuals vs. multiple regression. J Anim Ecol 71:542-545

Gamoun M (2014) Grazing intensity effects on the vegetation in desert rangelands of Southern Tunisia. J Arid Land 6:324-333 
Gaucher P, Paillat P, Chappuis C, Saint Jalme M, Lotfikhah F, Wink M (1996) Taxonomy of the houbara bustard Chlamydotis undulata subspecies considered on the basis of sexual display and genetic divergence. Ibis 138:273-282

Gintzburger G, Toderich KN, Mardonov BK, Mahmudov MM (2003) Rangelands of the arid and semi-arid zones in Uzbekistan. CIRAD, ICARDA, Paris

Goriup PD (1997) The world status of the houbara bustard Chlamydotis undulata. Bird Conserv Int 7:373-397

Graf RF, Bollmann K, Suter W, Bugmann H (2005) The importance of spatial scale in habitat models: capercaillie in the Swiss Alps. Landsc Ecol 20:703-717

Gray TNE, Chamnan H, Collar NJ, Dolman PM (2009) Sex-specific habitat use by a lekking bustard: conservation implications for the critically endangered Bengal Florican (Houbaropsis bengalensis) in an intensifying agroecosystem. Auk 126:112-122

Gubin B (1992) Numbers, distribution and state of protection of the houbara bustard in the south of Kazakhstan. Bustard Studies 5:98-103

Gubin BM (2004) Drofa-krasotka (Houbara Bustard). Kolor, Almaty (in Russian)

Gubin B (2008) Numbers and seasonal distribution of Asian houbara (Chlamydotis undulata macqueenii) in Mangystau district (Kazakhstan). In: Spitsina VV (ed) Bustards of the Palearctic: breeding and conservation. Moscow, pp 108-129 (in Russian)

Hingrat Y, Saint Jalme M, Ysnel F, Le Nuz E, Lacroix F (2007) Habitat use and mating system of the houbara bustard (Chlamydotis undulata undulata) in a semi-deserticarea of North Africa: implications for conservation. J Ornithol 148:39-52

Hingrat Y, Saint Jalme M, Chalah T, Orhant N, Lacroix F (2008) Environmental and social constraints on breeding site selection. Does the exploded-lek and hotspot model apply to the houbara bustard Chlamydotis undulata undulata? J Avian Biol 39:393-404

Hirzel AH, Lay GL (2008) Habitat suitability modelling and niche theory. J Appl Ecol 45:1372-1381

Johnston A et al (2015) Modelling the abundance and distribution of marine birds accounting for uncertain species identification. J Appl Ecol 52:150-160

Koshkin MA, Collar NJ, Dolman PM (2014) Do sheep affect distribution and habitat of Asian Houbara Chlamydotis macqueenii? J Arid Environ 103:53-62

Launay F, Loughland R, Mukhina EA (1997a) Preliminary observations of the incubation and covey behaviour of Houbara Bustard Chlamydotis undulata macqueeni. Sandgrouse 19:51-55

Launay F, Roshier D, Loughland R, Aspinall SJ (1997b) Habitat use by houbara bustard (Chlamydotis undulata macqueenii) in arid shrubland in the United Arab Emirates. J Arid Environ 35:111-121

Lavee D (1988) Why is the houbara Chlamydotis undulata macqueenii still an endangered species in Israel? Biol Conserv 45:47-54

Le Cuziat J, Lacroix F, Roche P, Vidal E, Medail F, Orhant N, Beranger PM (2005a) Landscape and human influences on the distribution of the endangered North African houbara bustard (Chlamydotis undulata undulata) in Eastern Morocco. Anim Conserv 8:143-152

Le Cuziat J, Vidal E, Roche P, Lacroix F (2005b) Human activities affect the potential distribution of the Houbara Bustard Chlamydotis undulata undulata. Ardeola 52:21-30

NASA Ma (2011) ASTER Global Digital Elevation Model V2. The Ministry of Economy, Trade and Industry (METI) of Japan and the United States National Aeronautics and Space Administration (NASA)

Mitropolsky OV, Mukhina EA, Nazarov OP (1996) Houbara Bustard

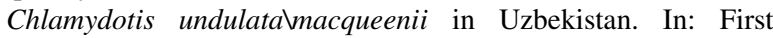
meeting of the IUCN SSC houbara bustard working group. Muscat, Oman

Moreira F, Morgado R, Arthur S (2004) Great bustard Otis tarda habitat selection in relation to agricultural use in southern Portugal. Wildl Biol 10:251-260

Oppel S, Meirinho A, Ramírez I, Gardner B, O’Connell AF, Miller PI, Louzao M (2012) Comparison of five modelling techniques to predict the spatial distribution and abundance of seabirds. Biol Conserv 156:94-104

Peterson AT (2006) Uses and requirements of ecological niche models and related distributional models. Biodiversity Informatics 3:59-77

R Core Team (2013) R: a language and environment for statistical computing. R Foundation for Statistical Computing. http://www. R-project.org/. Vienna, Austria

Rachkovskaya EI (1995) Vegetation map of Kazakhstan and Middle Asia (Desert region). Russian Academy of Sciences, Saint Petersburg

Renwick AR, Massimino D, Newson SE, Chamberlain DE, PearceHiggins JW, Johnston A (2012) Modelling changes in species' abundance in response to projected climate change. Divers Distrib 18:121-132

Riou S, Judas J, Lawrence M, Pole S, Combreau O (2011) A 10-year assessment of Asian Houbara Bustard populations: trends in Kazakhstan reveal important regional differences. Bird Conserv Int 21:134-141

Royle JA (2004) N-mixture models for estimating population size from spatially replicated counts. Biometrics 60:108-115

Seddon PJ, Saint Jalme M, van Heezik Y, Paillat P, Gaucher P, Combreau O (1995) Restoration of houbara bustard populations in Saudi Arabia: developments and future directions. Oryx 29:136-142

Segurado P, Araújo MB (2004) An evaluation of methods for modelling species distributions. J Biogeogr 31:1555-1568

Simpson EH (1949) Measurement of diversity. Nature 163:688

Tourenq C, Combreau O, Pole SB, Lawrence M, Ageyev VS, Karpov AA, Launay F (2004) Monitoring of Asian houbara bustard Chlamydotis macqueenii populations in Kazakhstan reveals dramatic decline. Oryx 38:62-67

Tourenq $\mathrm{C}$ et al (2005) Alarming houbara bustard population trends in Asia. Biol Conserv 121:1-8

van Heezik Y, Seddon PJ (1999) Seasonal changes in habitat use by houbara bustards Chlamydotis undulata macqueenii in northern Saudi Arabia. Ibis 141:208-215

Waber K, Spencer J, Dolman PM (2013) Achieving landscape-scale deer management for biodiversity conservation: the need to consider sources and sinks. J Wildl Manage 77:726-736

Yang WK, Qiao JF, Combreau O, Gao XY, Zhong WQ (2002a) Display-sites selection by houbara bustard (Chlamydotis undulata macqueenii) in Mori, Xinjiang, People's Republic of China. J Arid Environ 51:625-631

Yang WK, Qiao JF, Combreau O, Yao J, Gao XY, Zhong WQ (2002b) Breeding habitat selection by houbara bustard (Chlamydotis undulata macqueenii) in Mori, Xinjiang, China. Sci China Ser D Earth Sci 45:1-10 